Vol. 13 , No. 1

ISSN: 2085 - 4609 (Print), e- ISSN 2656-0208

Journal homepage: bit.ly/UltimaComm

\title{
Partisan Selective Exposure in COVID-19 News
}

\section{Anindita Widiastuti, Kunto Adi Wibowo, \& Benazir Bona Pratamawaty}

To cite this article:

Widiastuti, A., Wibowo, K.A. \& Pratamawaty, B.B. (2021). Partisan Selective Exposure in COVID-19 News, Ultimacomm, 13(1), 93-107. https://doi.org/https://doi.org/10.31937/ultimacomm.v13i1.1999

Ultimacomm publishes research articles and conceptual paper in the field of communication, mainly digital journalism and strategic communication. It is published twice a year by the Faculty of Communication of Universitas Multimedia Nusantara

Submit your article to this journal [ 


\title{
When Politics and Health Collide: \\ Selective Exposure in COVID-19 News
}

\author{
Anindita Widiastuti, Kunto Adi Wibowo, Benazir Bona Pratamawaty \\ Universitas Padjajaran \\ Email: aninditawidiastuti@gmail.com, kunto.a.wibowo@unpad.ac.id, benazir.bona@unpad.ac.id
}

Received Apr. 14, 2021; Revised Jun. 16, 2021; Accepted Jun. 26, 2021

\begin{abstract}
Globally, COVID-19 news is highly motivated by political interests. In Indonesia, one of the reasons for political polarization is the contrast in how the COVID-19 is being dealt with by Anies as the Governor of DKI Jakarta who had suggested a lockdown to Jakarta as the capital city since the beginning of the pandemic, but is rejected by Jokowi as the President of the Republic of Indonesia who preferred the large-scale-social-restrictions policy. This study examines the effect of selective exposure in COVID-19 news in Indonesia's political context where everything is extremely polarized. Selective exposure theory where audiences will spend more time reading news that is aligned with their political attitudes is tested in the COVID-19 context in Indonesia. This experimental study employed a $2 \times 3$ block factorial between-subjects design. A total of 216 participants are randomly assigned to groups with more politically reinforcing news, more politically challenging news, and neutral news after being priorly grouped according to their political attitudes. Experimental results showed how the participants in the group where more politically reinforcing news is available spent more time on news that supports their political attitudes. Whereas, participants in the group where more politically challenging news is available spent more time on news that contradicts their political attitudes. Discussions about information availability in a news environment and its influence to selective exposure is discussed by the end of this paper.
\end{abstract}

Keywords: selective exposure, political polarization, COVID-19, news environment, information availability

\section{INTRODUCTION}

Ever since Indonesia's two first confirmed COVID-19 cases in March 2020 (Yulisman, 2020), the reported total of deaths and cases of COVID-19 kept increasing significantly. By November 2020, it has reached half of a million cases (Fachriansyah, 2020). Back in March 2020, the Governor of Jakarta, Anies Baswedan proposed a quarantine scenario of a lockdown to Jakarta as the capital city of Indonesia. This was turned down by the President of the Republic of Indonesia, Joko Widodo who preferred the large-scale-socialrestrictions policy where citizens could simply do physical distancing as a preventive measure instead (Gorbiano \& Sutrisno, 2020). Aside from this response contrast, the April 
2020 survey by SMRC that involved 1200 respondents found how $41 \%$ respondents such as the West Java's citizens felt as if the government's responses towards the COVID-19 pandemic is too slow. These respondents happened to come from the provinces which didn't succeed Jokowi in the 2019 election. Contrarily, in the provinces where Jokowi won the 2019 election, such as Bali, East Java, and Central Java, a total of 52\% respondents felt as if the government had responded to the COVID-19 pandemic quickly enough. The contrast in the political responses made by Jokowi and Anies along with the polarized public perception became a few reasons for political polarization to amplify during the COVID-19 pandemic in Indonesia (Warburton, 2020).

Political polarization is found by Stroud (2010) to lead to partisan selective exposure, a behavior where one selects information following one's own political predispositions. This politically-led selective behavior is not to ignore considering how Christensen, et al. (2020) found political ideology as the strongest factor in attitudes towards COVID-19. Even before the pandemic, political ideology had also been found to have a huge role in adults' attitudes and behaviors. Partisanship was found to have played a significant role in perceptual differences in the climate change issue (Kim, 2011). In another context, ideology in a study by Dulkiah (2020) is found to have a significant impact on radicalism in Indonesia. A study about the COVID-19 news coverage by Hart, et al. (2020) found more politicians appearing in newspapers compared to the scientists. The study saw the potential effect of this intense polarization in the COVID-19 news coverage to individuals' attitudes on COVID-19. Evidence ruling out the role of political ideology and the polarization in many contexts lead this study to explore partisan selective exposure in certain COVID-19 news environments in Indonesia.

Previous studies, such as from Garrett (2009) found how individuals select more opinionreinforcing compared to opinion-challenging news. Aligning, Ardi (2019) found how partisans are more likely to disregard misinformation when it sources from the political figures that they support. Partisans tend to perceive information coming from the figures they support as high-quality information. They also tend to criticize opposing information about the figures they support. Political polarization's ability to affect individuals' attitudes is concerning. The COVID-19 situation makes it even more concerning considering how political polarization will be affecting people's attitude towards the health policies made by certain political figures (Havey, 2020). The infodemic, which provides people to read more information available online, had also been seen to threaten the international mitigation efforts on COVID-19 (Melki, 2020).

Jokowi and Anies were selected as the political figures that the participants get to choose considering the political polarization between Jokowi and Anies' supporters. The experiment is conducted online to citizens currently living in the Jakarta metropolitan area. This is considering how the daily Jakarta is crowded by the Jakarta metropolitan area's citizens which consist of citizens from the city of Jakarta, Bogor, Depok, Tangerang, and Bekasi. They come to work, study, or hang out in Jakarta by the morning and go back 
home in the afternoon. These individuals' lifestyles then are the one to be most affected by the health policies made by Jokowi as the central government who's located in Jakarta and Anies as the governor of Jakarta himself.

Selective exposure is not studied well enough in Indonesian samples. In a meta-analysis of selective exposure studies by Hart, et al. (2009), it was examined how $46 \%$ or most selective exposure studies with a total of 147 studies were conducted in the United States and Canada. $46 \%$ of the studies were conducted in Germany, while 3\% was conducted in Australia, and only $1 \%$ was conducted in Italy. Each country adapts a distinct communication, culture, and political structure. Hence, it is required to add more studies on selective exposure in Indonesia. By studying how individuals' political attitudes may influence their health attitudes, this study will also contribute to the political communication studies (McNair, 2018) and the health communication studies (Beato \& Telfer, 2010).

It's theorized how people are guided by their ideological differences when interpreting and reacting to aspects of their social and political environments (Abramowitz \& Saunders, 2006; Jost, Nosek, \& Gosling, 2008). These ideology differences lead individuals to adopt certain political perspectives (Alford, Funk, \& Hibbing, 2005). As an effect of fundamental values on attitudes, while as opposed to an effect of identity on attitudes, one's ideologically based manner will control one stance on an issue (Boninger, Krosnick, \& Berent, 1995). Therefore, one's political ideology will drive one's behavior on specific issues accordingly.

Most previous research regarding political ideology takes place in the United States, where the most discussed ideological feature has been the right versus the left, or the Conservative versus the Liberal (Malka \& Lelkes, 2010). These political ideologies have become a principal reason in how citizens approach the news. These days, where the availability of news is endless, the news environment between Conservative Republicans and Liberal Democrats is entirely different. People may either pick or filter out news on topics they either align or oppose with. It's extremely easy for individuals nowadays to look for like-minded news. For example, Keith Olbermann can provide news for Liberal Democrats, while Bill O'Reilly can provide news for Conservative. This usage case of politically like-minded news can be defined as partisan selective exposure (Stroud, 2011).

Pilot understanding of selective exposure referred to Festinger's (1957) cognitive dissonance research. The cognitive dissonance framework has been employed in studies to see media users' preferences towards messages aligning with their personal values due to their need for consistency. Historically, the selective exposure's term has been linked to reinforcement-seeking exposure motivations. Selective exposure has been generally studied in political or health communication's context and has been mainly referred to as a preference for information that aligns with one's existing attitudes (Lazarsfeld, 
Berelson, \& Gaudet, 1944). In the COVID-19 context, Gadarian, et al. (2021) found how partisanship influences policy preferences as well as the health behaviors of Americans. In another study, Young and Bleakley (2020) introduced the Ideological Health Spirals Model which may be used to explain the operation of political dynamics in health behaviors context, such as towards the COVID-19.

Unlike uses-and-gratifications research where survey measures may be used to capture message exposure by assuming full awareness on media users, scientists have been arguing how users are unconscious of their motives for media selections and hence are not in a position to report their motives through survey measures. Damaged recall, as well as inaccurate response scales, are also seen to undermine self-report data's validity. To shift the problems reported on self-reports as used in uses-and-gratifications research, the selective exposure paradigm employs behavioral observation measures in capturing individuals' messages' exposure. Ideally, these observations are conducted unobtrusively in order to keep the participants of a research to be biased by the operation of the data collection. For this reason, experimental design is the most common method in selective exposure exploration (Knobloch-Westerwick, 2015).

Grounds for choices in selective exposure may vary, two of them as in KnoblochWesterwick (2015) are concrete selection and avoidance. It is discussed how devoting one's time, and therefore selectively exposing oneself to a media content may serve to represent one's selective exposure. Hence, article selection and exposure time in seconds or percentages have been generally used to measure selective exposure. Another reason for selective choices might be for avoiding other available media content. Underlining on the avoidance behavior, selective behavior is therefore commonly found in political and health communication studies. Selectivity is concerned to be an issue in both the political and health communication context due to the lack of participation in democratic deliberations or due to the danger of disregarding relevant health information. These concerns may be helped by exposing oneself to diverse viewpoints.

A condition for selective exposure to occur is the availability of media and message choices where individuals' selectivity may be guided by their own certain attitudes which lead their choice preferences (Knobloch-Westerwick, 2015). Contents spreading in the media are escalating quickly everyday that it is essentially unlimited (Anderson, 2009). Unlike traditional media, the current media is providing audiences with a wide selection of information allowing for selectivity as the audiences tour between content sources (Webster, 2011). This availability of unlimited online news content assists individuals' selective exposure to information aligned to their prior attitudes (Stroud, Media use and political predispositions: Revisiting the concept of selective exposure, 2008), whether they'll spend more or less time reading the content. 
Hypothesis 1: Time spent on politically opinion-reinforcing news varies across experimental conditions.

Hypothesis 2: Time spent on politically opinion-challenging news varies across experimental conditions.

\section{METHOD}

Using the quantitative approach, this experimental study employed a 2 (blocked : Pro Jokowi vs. Pro Anies) $\times 3$ (experimental variables : Pro vs. Contra vs. Control) block factorial between-subjects design as described in Figure 1. The Pro Jokowi blocks consist of participants identifying their political attitudes towards Jokowi, while the Pro Anies blocks consist of participants identifying their political attitudes towards Anies. 216 participants are equally distributed and randomly assigned to experimental conditions available. The pro experimental group contains three politically reinforcing news and one politically challenging news. For Pro Jokowi blocks, politically reinforcing news are news that supports Jokowi. The news are designed to be polarized, hence the politically reinforcing news for Pro Jokowi blocks is simultaneously politically challenging news for Pro Anies blocks. The contra experimental group contains three politically challenging news and one politically reinforcing news, while the control or the neutral group contains an equal of two politically reinforcing news and two politically challenging news.

Figure 1. The 2x3 Blocked Design

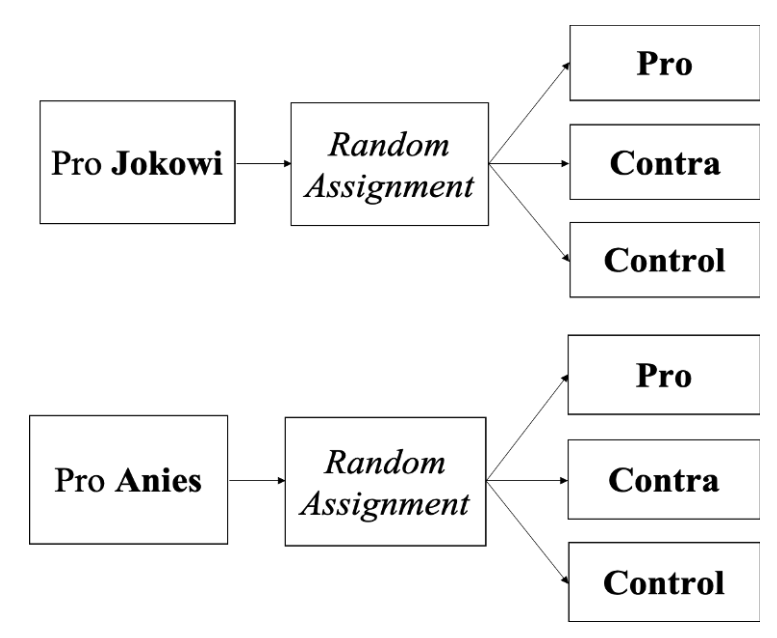

Due to the continuously alternating political situation and along with the everyday update of the COVID-19 policies, convenience sampling was used in order to get as many samples in as little span of time as possible. With an effect size of 0,38 as obtained from Hart, et al (2009), G*Power was used to determine the minimum sample required, which was 144 samples in total. Before excluding 26 invalid data, the data collection process managed to 
get 252 raw samples. A one-way ANOVA was conducted to examine the time differences spent by participants between experimental and control groups.

The study was conducted through a designed behavior tracking web. After participants received a website link that could be accessed from a web browser on their mobile devices, they were requested for a consent, including their consent towards any kind of data collection that will be conducted. After consent was given, the experiment started by measuring their political attitudes, either towards the President of Indonesia, Joko Widodo or towards the Governor of Jakarta, Anies Baswedan. The participants then were instructed to browse over the four news headlines, and choose to read whichever news they are willing to read. The content of the news will pop up once the participant has clicked on a specific headline, as illustrated in Figure 2.

Figure 2. Screenshot of The Stimuli Page

\begin{tabular}{|c|c|}
\hline \multicolumn{2}{|c|}{$\begin{array}{l}\text { Silahkan klik judul berita yang hendak Anda baca. Anda dapat memilih } \\
\text { untuk membaca satu hingga seluruh berita yang tersedia. }\end{array}$} \\
\hline $\begin{array}{l}\text { Jokowi: Kepala } \\
\text { Daerah Tidak Perlu } \\
\text { Terburu-buru } \\
\text { PSBB }\end{array}$ & $\begin{array}{l}\text { Sejak Februari } 2020 \text {, Anies telah melakukan langkah- } \\
\text { langkah antisipasi penyebaran virus Corona di DKI } \\
\text { Jakarta. } \\
\text { Sebaliknya, pemerintah Joko Widodo justru terkesan }\end{array}$ \\
\hline $\begin{array}{l}\text { Anies Lebih } \\
\text { Unggul Tangani } \\
\text { Virus Corona } \\
\text { Dibandingkan } \\
\text { Jokowi }\end{array}$ & $\begin{array}{l}\text { meremehkan virus mematikan asal Wuhan China itu. } \\
\text { Ketika Virus Corona mewabah di beberapa negara, } \\
\text { presiden Jokowi tidak melakukan upaya pencegahan } \\
\text { secara kongkrit. }\end{array}$ \\
\hline $\begin{array}{l}\text { Dalam } \\
\text { penanganan } \\
\text { Covid-19, Anies The } \\
\text { Real Leader }\end{array}$ & $\begin{array}{l}\text { Empat arahan Jokowi terkait virus Corona pada Selasa } 25 \\
\text { Februari } 2020 \text { sama sekali tak menyinggung bagaimana } \\
\text { cara mencegah dan menangani Virus Corona di } \\
\text { Indonesia. }\end{array}$ \\
\hline $\begin{array}{l}\text { Media Asing Sebut } \\
\text { Anies Rival Jokowi, } \\
\text { PKS: Dia Jaga } \\
\text { Jakarta dari } \\
\text { Pandemi }\end{array}$ & $\begin{array}{l}\text { Jokowi justru memberikan arahan kepada menteri } \\
\text { terkait peningkatan dalam sektor pariwisata agar } \\
\text { wisatawan mancanegara yang batal berwisata ke negara } \\
\text { terjangkit Virus Corona, bisa beralih ke Indonesia. }\end{array}$ \\
\hline & Selesai Membaca \\
\hline
\end{tabular}

The order of the headlines displayed on the stimuli page is randomized to a total of six positions for six random links. The stimuli page that appeared on each participant's page is according to the experimental condition they previously got assigned to. The system automatically redirected participants to the next page after 240 seconds on the stimuli page had passed. The maximum time an individual spent on the page, however, was only 203 seconds, $M=67$ seconds (SD = 0). The last section of the web requested participants for their demographic data.

Each news consists of 100 words in total, with a headline of $M=7.83$ words $(S D=2.32$ ), and a body content of $M=92.17$ words $(S D=2.32)$. To make sure that each stimulus worked as intended, it was pre-tested with 124 participants (Mage $=19.6, S D=4.15 ; 33 \%$ male). "The news are more in favor of" ( $0=$ Jokowi; $7=$ Anies) were tested as a statement 
put at each of the six news content. To remove any bias, the value of 0-7 was recorded without displaying the specific number to be seen by the participants examining it. The average score is between $M=1.18$ and $M=1.43$ for the "Pro Jokowi" articles and between $M=5.92$ and $M=6.14$ for the "Pro Anies" articles, as described in Table 1. As a within-group factor in a repeated-measures ANOVA, there was no significant differences in both "Pro Jokowi", $F(2,228)=1.37, p=.255, \eta 2=.011$, and in "Pro Anies" factor, $F(2$, $208)=1.45, p=.238, \eta 2=.012$. The results verified that the stimuli functioned as planned.

Table 1. Stimuli Test

\begin{tabular}{|c|c|c|}
\hline \multirow[t]{2}{*}{ News Headlines } & \multicolumn{2}{|c|}{ Partisan Stance } \\
\hline & M & SD \\
\hline \multicolumn{3}{|l|}{ Pro Jokowi (Contra Anies) } \\
\hline Jokowi: Tak Perlu Sok-sokan Lockdown & 1.2 & 1.6 \\
\hline Jokowi: Kepala Daerah Tidak Perlu Terburu-buru PSBB & 1.2 & 1.5 \\
\hline $\begin{array}{l}\text { Karena PSBB Total, Arief Poyuono: Nonaktifkan Anies } \\
\text { Baswedan! }\end{array}$ & 1.4 & 1.9 \\
\hline \multicolumn{3}{|l|}{ Pro Anies (Contra Jokowi) } \\
\hline $\begin{array}{l}\text { Anies Lebih Unggul Tangani Virus Corona Dibandingkan } \\
\text { Jokowi }\end{array}$ & 6.0 & 1.6 \\
\hline $\begin{array}{l}\text { Media Asing Sebut Anies Rival Jokowi, PKS: Dia Jaga Jakarta } \\
\text { dari Pandemi }\end{array}$ & 5.9 & 1.7 \\
\hline Dalam penanganan Covid-19, Anies The Real Leader & 6.1 & 1.5 \\
\hline
\end{tabular}

The news' headlines and contents' level of appeal were also tested to three groups of participants ( 1 = very not appealing; 7 = very appealing). The first group of 69 participants ( Mage $=20, S D=1.61 ; 33 \%$ male) tested three "Pro Jokowi" and one "Pro Anies" news' headlines, $F(3,204)=1.59, p=.193, \eta 2=.023$, and contents, $F(3,187)=.407, p=.73, \eta 2$ $=.006$. The second group of 76 participants (Mage $=20, S D=1.87 ; 30 \%$ male) tested three "Pro Anies" and one "Pro Jokowi" news' headlines, $F(3,225)=1.6, p=.197, \eta 2=$ .021 , and contents, $F(3,196)=1.07, p=.358, \eta 2=.014$. The third group of 71 participants (Mage $=20, S D=2 ; 24 \%$ male) tested two "Pro Anies" and two "Pro Jokowi" news' headlines, $F(3,210)=1.28, p=.283, \eta 2=.018$, and contents, $F(3,210)=.68, p=.567, \eta 2$ $=.010$. Therefore, all of the news' headlines and contents did not significantly differ on the level of appeal. 
Participants were shown to a blank horizontal multiple choice with "Jokowi" on the left side of the multiple-choice, which was coded as one, and "Anies" on the right side of the multiple-choice which was coded as four ( 1 = Jokowi; 4 = Anies). Accordingly, a value of one and two were coded to identify a participant as a Pro Jokowi, while a value of four and three were coded to identify a participant as a Pro Anies.

Garrett (2009) had previously conducted a web-administered behavior-tracking study to record participants' selective exposure behavior. This study, therefore, employed a similar web-administered behavior-tracking device to collect selective exposure data. Participants' browsing activity on the stimuli page was tracked and the amount of time spent on each news was collected. The average time spent on each news was $M=24$ seconds $(S D=0)$.

\section{RESULT}

From an initial of 252 data collected, 17 data were excluded given how the participants failed to follow the instruction, where they didn't choose any news to read, and therefore their participation can't be used to measure their exposure behavior. 19 more data was excluded, since participants were detected to be staying outside of the Jakarta metropolitan area during the data collection, given how they may not be as affected as the people who are actually living in the Jakarta metropolitan area, where the public policy implemented by both Jokowi and Anies directly affected their work and lifestyle. These cases left the study with 216 data that were employed by participants on either their personal mobile devices such as their laptop (36.6\%) or their mobile phone $(63.4 \%)$.

The 216 dataset consists of participants staying in the Jakarta metropolitan area during the data collection (Jakarta (78.2\%), Bogor (5.1\%), Depok (1.4\%), Tangerang (5.1\%), and Bekasi $(10.2 \%)$ with a mean age of 19.99 (SD = 1.82), with $29.1 \%$ of male participants. $55.1 \%$ of participants are identified to be a Jokowi stance, while $44.9 \%$ are identified to be an Anies stance. The majority of $69.9 \%$ of participants had a high school degree, followed by $28.2 \%$ of participants with a bachelor's degree. Participants' reading frequency of online articles' sources in the last month were calculated $(0=$ never; $7=$ always), with the news' portal Kompas scored $M=3.73$ (SD = 1.90), Detik with $M=3.40$ ( $S D=1.97)$, Kumparan with $M=3.1$ (SD = 2.05), Liputan6 with $M=2.63(S D=1.92)$, and TribunNews with $M=2.43$ (SD = 2.01). Data on participant's spending for their internet cost was collected as well, with the majority of $49.3 \%$ participants that spent less than Rp.100.000 on the internet for the last month.

For the time spent on the pro experimental condition or the group with more politically reinforcing news, a one-way ANOVA test demonstrated a significant difference in time spent across the experimental conditions $F(2,162)=11, p<.001$. Hence, we accept the first hypothesis. For a better detail on the differences between conditions, a T-Test revealed a significant difference between the pro $(M=33.8, S D=32.75)$ with the contra 
condition $(\mathrm{M}=13.7, \mathrm{SD}=15.87), \mathrm{t}(96.103)=4.63, \mathrm{p}<.001$, as well as a significant difference between the pro $(M=33.8, S D=32.75)$ with the control condition $(M=22.9$, $\mathrm{SD}=25.5), \mathrm{t}(128.422)=2.192, \mathrm{p}=.030$, as well as a significant difference between the control $(M=22.9, S D=25.5)$ with the pro condition $(M=13.7, S D=15.87), t(115.666)=$ 2.609, $p=.010$.

For the time spent on the contra experimental condition or the group with more politically challenging news, a one-way ANOVA test demonstrated a significant difference in time spent across the experimental conditions $F(2,162)=11, p<.001$. Hence, we accept the second hypothesis as well. For a better detail on the differences between conditions, a $\mathrm{T}$-Test revealed a significant difference between the contra $(\mathrm{M}=37.1, \mathrm{SD}=44.35)$ with the pro condition $(\mathrm{M}=11.9, \mathrm{SD}=15.43), \mathrm{t}(94.473)=4.652, \mathrm{p}<.001$, as well as between the pro $(M=11.9, S D=15.43)$ with the control condition $(M=31.8, S D=36.6), t(94.659)$ $=4.206, \mathrm{p}<.001$. However, no difference was found between the pro $(M=13.7, S D=$ $15.87)$ with the control condition $(M=22.9, S D=25.5), t(142.876)=.795 p=.428$.

On politically reinforcing news exposure where participants exposed themselves to more opinion-reinforcing news, average of time spent by participants varies across conditions of pro $(M=33.8, S D=32.7)$, contra $(M=13.7, S D=15.9)$, and control $(M=22.9, S D=$ 25.5), as seen in Figure 3.

Figure 3. Mean Plots Between the Time Spent on Opinion-Reinforcing News

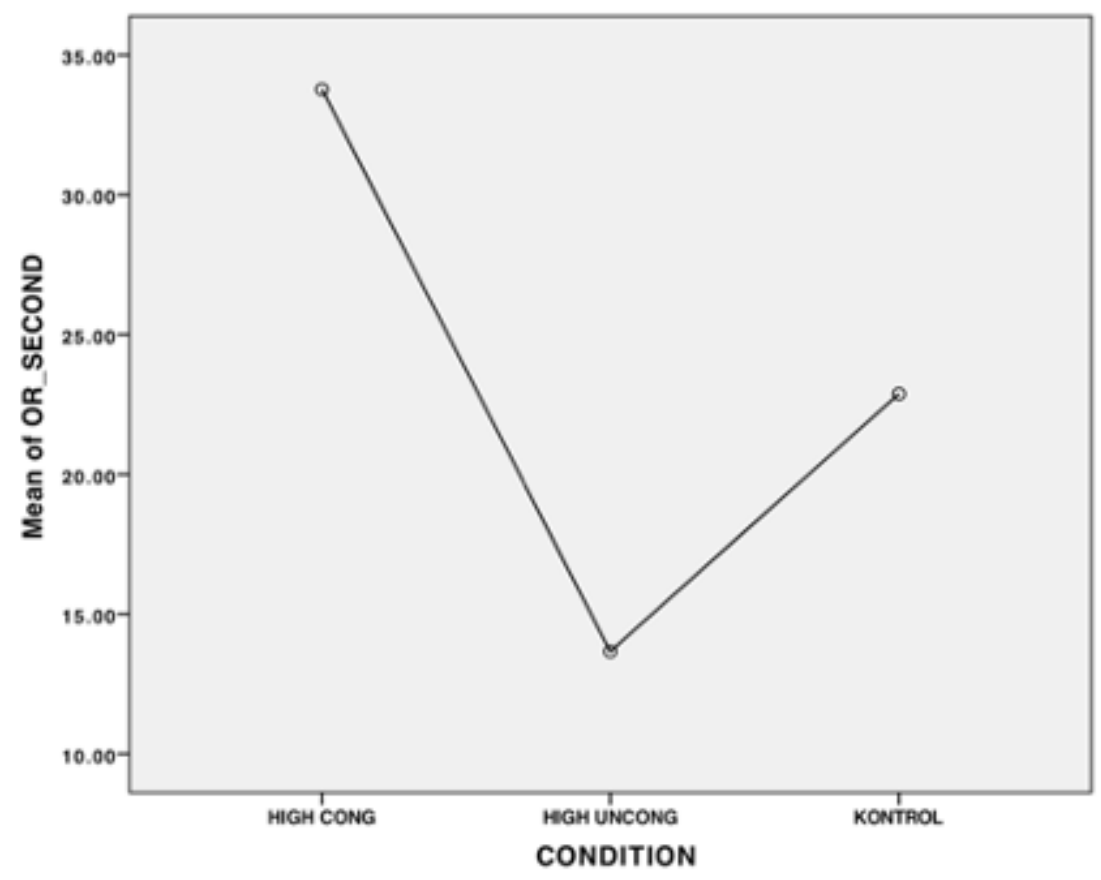


On politically challenging news exposure where participants exposed themselves to more opinion-challenging news, average of time spent by participants also varies across conditions of pro $(M=11.9, S D=15.4)$, contra $(M=37.1, S D=44.3)$, and control $(M=$ $31.8, \mathrm{SD}=36.6)$, as seen in Figure 4 .

Figure 4. Mean Plots Between the Time Spent on Opinion-Challenging News

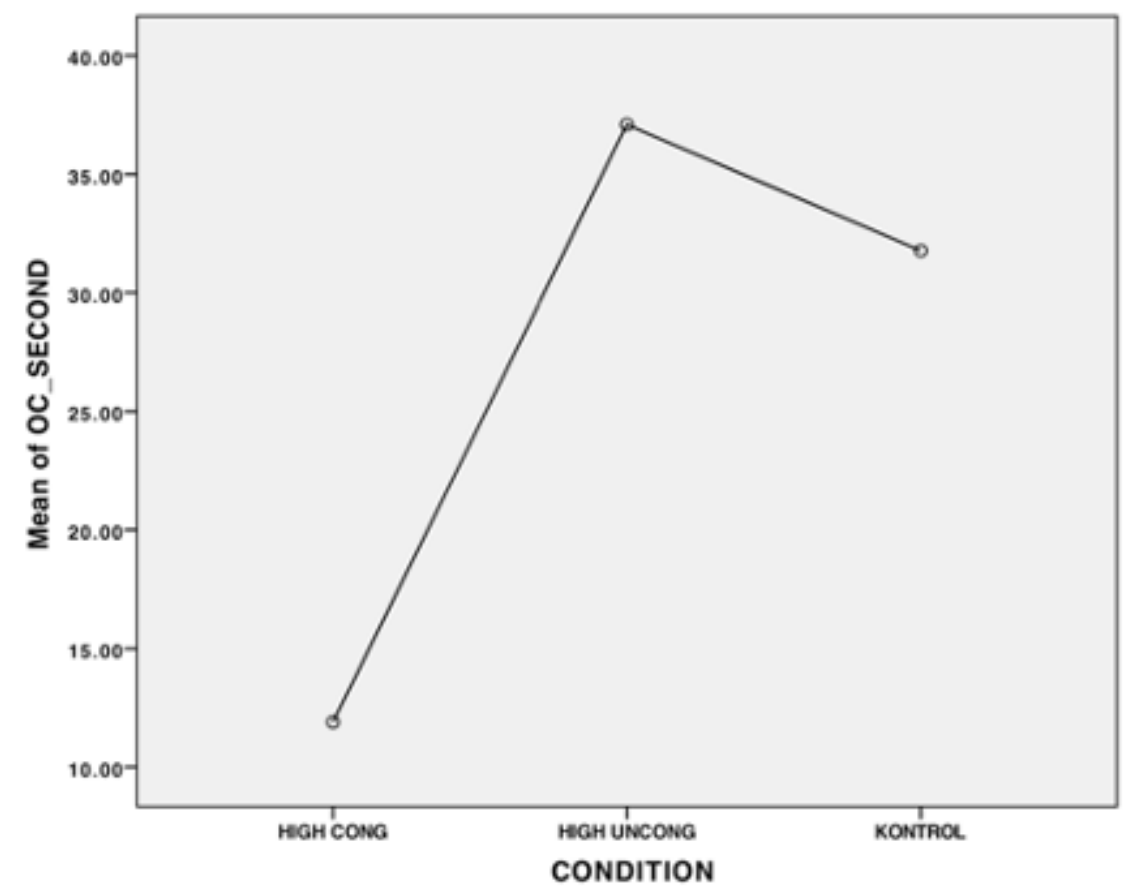

\section{DISCUSSION}

To examine the effect of selective exposure in the polarized COVID-19 news environment, this study employed the selective exposure framework where one's political attitude guides one's news exposure. It is assumed how individuals have a tendency to expose themselves to information aligned with the political values they've pre-acquainted with (Stroud, 2011). Aligning with the assumption, our data shows how most time is spent on politically reinforcing news when participants are placed in the pro condition $(M=33.8$, $S D=32.7$ ) where more politically reinforcing news were available. This result also aligns with the findings from Barnidge, et al. (2017) where participants spent more time on opinion-reinforcing news when supported by a supportive news environment that provided more like-minded news.

Similarly, the study by Garrett (2009) also found how individuals tend to be more interested in reading and therefore spend more time in news they expect to support their own opinion. At the same time, however, due to one's tendency to criticize others' perspectives, individuals are also contrarily found to display more interest in news against their values. This aligns with our data on politically challenging news where most time is 
spent at the contra condition $(M=37.1, S D=44.3$ ) where more politically challenging news were available. No significant time difference between the seconds spent in between the contra and the control condition ( $\mathrm{M}=31.8, \mathrm{SD}=36.6$ ) imply how participants tend to be more interested in criticizing other perspectives compared to spending time on like-minded news. This aligns with previous studies, such as by Zillmann, et al. (2004) and Meffert, et al. (2006). This also may be due to how it is more challenging to process disconfirming information (Ditto \& Lopez, 1992) and therefore resulted in individuals spending more time on challenging information.

Overall, data shows how participants' political attitudes, to whomever they are leaning to, be it to Jokowi or Anies played a role in selective exposure and COVID-19 news behavior. The results where the participants in the politically reinforcing news environment spent more time in politically reinforcing news, as well as how the participants in the politically challenging news environment spent more time in politically challenging news showed how participants' exposure depends on their news environment. This aligns with the findings by Wibowo (2018) where selective exposure is also found to be affected by the news environment. The news environment is manipulated by the information availability in the experimental conditions. This denotes how information availability is a factor that may lead individuals' selective exposure behavior.

Democratic consequences of selective exposure asserts how the ideal news environment is an equal one. An equal news environment must involve an equal politically reinforcing and challenging news content. This news environment may help to open people up to broader perspectives of realities and reduce polarization-led behavior. This will help people to make wiser and non-polarized decisions towards the COVID-19 behavior. Another situation that must be taken into consideration is the fact how completely getting rid of the political polarization in the society is slightly an impossible task. However, it's only appropriate for political figures to play their role in the mitigation of the pandemic by keeping their political agendas aside and join their hands to have the same vision in supporting the COVID-19's policies.

\section{CONCLUSION}

Selective exposure behavior on both politically reinforcing and challenging news depends on the availability of either reinforcing or challenging news in a news environment. When an individual is placed in a news environment where one is provided with more politically reinforcing news, more time would be spent on the politically reinforcing news. As well as how when an individual is placed in a news environment where one is provided with more politically challenging news, more time would be spent on the politically challenging news. A politically reinforcing news environment might lead to a better political participation. However, with limited perspectives, the people will be less-informed. To be rational, Lane \& Sears (1964) mentioned how one must be open to all perspectives, which 
is done by exposing oneself to an equal news environment where both opinionreinforcing and opinion-challenging news are available. In supporting efforts towards the COVID-19 mitigation, each party, from political figures, health experts, to world leaders must be able to align their visions, keep aside their personal agendas, and act wisely in being a public guide in behaving towards the COVID-19 pandemic. Even if previous studies have ruled out the possibility of reasons for a certain selective exposure behavior, the methodology used in this study doesn't allow us to figure out the exact reason for each selective behavior. Do participants actually spend more time on challenging news because they are interested in criticizing them? Further research may also consider measuring participant's critical-thinking ability, open-mindedness, reading literacy, availability, and such before measuring their selective exposure behavior. 


\section{REFERENCES}

Abramowitz, A. I., \& Saunders, K. L. (2006). Exploring the bases of partisanship in the American electorate: Social identity vs. ideology. Political Research Quarterly, 59(2), 175-187.

Alford, J. R., Funk, C. L., \& Hibbing, J. R. (2005). Are political orientations genetically transmitted? American Political Science Review, 99(2), 153-167. https://doi.org/10.1017/S0003055405051579

Anderson, C. (2009). Free: The future of a radical price. New York: Hyperion.

Ardi, R. (2019). Partisan Selective Exposure to Fake News Content. Makara Hubs-Asia, 23(1), 6-16. DOI:10.7454/hubs.asia.1160219

Barnidge, M., Gunther, A. C., Kim, J., Hong, Y., Perryman, M., Tay, S. K., \& Knisely, S. (2017). Politically Motivated Selective Exposure and Perceived Media Bias. Communication Research, 47(1), 82-103. https://doi.org/10.1177/0093650217713066

Beato, R. R., \& Telfer, J. (2010). Communication as an Essential Component of Environmental Health Science. Journal of Environmental Health, 73(1), 24-25.

Boninger, D. S., Krosnick, J. A., \& Berent, M. K. (1995). Origins of attitude importance: Self-interest, social identification, and value relevance. Journal of Social and Personality Psychology, 68(1), 61-80. https://doi.org/10.1037/0022-3514.68.1.61

Christensen, S. R., Pilling, E. B., Eyring, J. B., Dickerson, G., Sloan, C. D., \& Magnusson, B. M. (2020). Political and personal reactions to COVID-19 during initial weeks of social distancing in the United States. PLOS ONE, 15(9), 1-16. https://doi.org/10.1371/journal.pone.0239693

Dulkiah, M. (2020). Pengaruh Ideologi Terhadap Sikap Radikal Pimpinan Pondok Pesantren di Tasikmalaya. Jurnal IImiah Nasional, 2(3), 118-127.

Ditto, P. H., \& Lopez, D. F. (1992). Motivated skepticism: Use of differential decision criteria for preferred and nonpreferred conclusions. Journal of Personality and Social Psychology, 63(4), 568-584. https://doi.org/10.1037/0022-3514.63.4.568

Fachriansyah, R. (2020, November 23). The Jakarta Post. Retrieved December 8, 2020, from Indonesia surpasses half a million coronavirus cases: https://www.thejakartapost.com/news/2020/11/23/indonesia-surpasses-half-amillion-coronavirus-cases.html

Festinger, L. (1957). A theory of cognitive dissonance. Stanford, CA: Stanford University Press.

Gadarian, S. K., Goodman, S. W., \& Pepinsky, T. B. (2021). Partisanship, health behavior, and policy attitudes in the early stages of the COVID-19 pandemic. PLOS ONE, 16(4), 1-13. https://doi.org/10.1371/journal.pone.0249596 
Garrett, R. K. (2009). Echo chambers online?: Politically motivated selective exposure among Internet news users. Journal of Computer-Mediated Communication, 14(2), 265-285. https://doi.org/10.1111/j.1083-6101.2009.01440.x

Gorbiano, M. I., \& Sutrisno, B. (2020, March 3). The Jakarta Post. Retrieved December 8, 2020, from Jokowi refuses to impose lockdown on Jakarta: https://www.thejakartapost.com/news/2020/03/30/jokowi-refuses-to-imposelockdown-on-jakarta.html

Hart, P. S., Chinn, S., \& Soroka, S. (2020). Politicization and Polarization in COVID-19 News Coverage. Science Communication, 42(5), 679-697. https://doi.org/10.1177/1075547020950735

Hart, W., Albarracin, D., Eagly, A., Brechan, I., Lindberg, M., \& Merrill, L. (2009). Feeling Validated Versus Being Correct: A Meta-Analysis of Selective Exposure to Information. Psychological bulletin, 135(4):555-88. doi: 10.1037/a0015701.

Havey, N. F. (2020). Partisan public health: how does political ideology influence support for COVID-19 related misinformation? Journal of Computational Social Science. doi: 10.1007/s42001-020-00089-2

Jost, J. T., Nosek, B. A., \& Gosling, S. D. (2008). Ideology: Its resurgence in social, personality, and political psychology. Perspectives on Psychological Science, 3(2), 126-136. https://doi.org/10.1111/j.1745-6916.2008.00070.x

Kim, K. S. (2011). Public understanding of the politics of global warming in the news media: the hostile media approach. Public Understanding of Science, 20(5), 690705. https://doi.org/10.1177/0963662510372313

Knobloch-Westerwick, S. (2015). Choice and Preferences in Media Use. New York, NY: Routledge.

Lane, R. E., \& Sears, D. O. (1964). Public Opinion. Englewood Cliffs, NJ: Prentice-Hall.

Lazarsfeld, P. F., Berelson, B., \& Gaudet, H. (1944). The people's choice: How the voter makes up his mind in a presidential campaign. New York, NY: Duell, Sloan, and Pearce.

Malka, A., \& Lelkes, Y. (2010). More than Ideology: Conservative-Liberal Identity and Receptivity to Political Cues. Social Justice Research, 23, 156-188. https://doi.org/10.1007/s11211-010-0114-3

McNair, B. (2018). An introduction to political communication. New York: Routledge. DOI: 10.1111/j.1460-2466.2006.00003.x

Melki, J., Tamim, H., Hadid, D., Makki, M., El Amine, J., \& Hitti, E. (2021). Mitigating infodemics: The relationship between news exposure and trust and belief in COVID19 fake news and social media spreading. PLOS ONE, 16(6). https://doi.org/10.1371/journal.pone.0252830

Stroud, N. J. (2011). Niche news: The politics of news choice. New York: Oxford University Press. 
Stroud, N. J. (2010). Polarization and Partisan Selective Exposure. Journal of

Communication, 60(3), 556-576. https://doi.org/10.1111/j.1460-

2466.2010.01497.x

Stroud, N. J. (2008). Media Use and Political Predispositions: Revisiting the Concept of Selective Exposure. Political Behavior, 30(3), 341-366.

https://doi.org/10.1007/s11109-007-9050-9

Warburton, E. (2020, April 28). CARNEGIE. Retrieved December 8, 2020, from Indonesia:

Polarization, Democratic Distress, and the Coronavirus:

https://carnegieendowment.org/2020/04/28/indonesia-polarization-democratic-

distress-and-coronavirus-pub-81641\#tableContents

Webster, J. G. (2011). The Duality of Media: A Structurational Theory of Public Attention.

Communication Theory, 21(1), 43-66. https://doi.org/10.1111/j.1468-

2885.2010.01375.x

Wibowo, K. (2018). Information Availability and Congeniality, Selective Exposure, and Reinforcement Effect. [Doctoral dissertation, Wayne State University Dissertations]. https://digitalcommons.wayne.edu/oa_dissertations/1975/

Young, D. G., \& Bleakley, A. (2020). Ideological Health Spirals: An Integrated Political and Health Communication Approach to COVID Interventions. International Journal of Communication, 14, 3508-3524

Yulisman, L. (2020, March 2). The Straits Times. Retrieved December 18, 2020, from Mother and daughter test positive for coronavirus in Indonesia, first confirmed cases in the country: https://www.straitstimes.com/asia/se-asia/indonesiaconfirms-two-coronavirus-cases-president

Zillmann, D., Chen, L., Knobloch, S., \& Callison, C. (2004). Effects of Lead Framing on Selective Exposure to Internet News Reports. Communication Research, 31(1), 5881. https://doi.org/10.1177/0093650203260201 